\title{
Semua Orang Bisa Jadi Detektif Bahan Kimia Obat dalam Jamu Dengan Strip Test
}

\author{
Aliya Nur Hasanah
}

Fakultas Farmasi Universitas Padjadjaran, Sumedang, Jawa Barat, Indonesia

Terbit online : 17 Juni 2016

\section{Abstrak:}

Bangsa Indonesia telah lama mengenal dan menggunakan tanaman-tanaman obat sebagai salah satu upaya dalam menanggulangi masalah kesehatan. Penggunaan obat tradisional khususnya jamu di Indonesia cukup tinggi, hampir 50\% masyarakat Indonesia terbiasa mengkonsumsi jamu. Tetapi peningkatan produksi, peredaran dan penggunaan jamu tersebut di sisi lain dicemari oleh adanya penambahan bahan kimia obat ke dalamnya. Sulitnya menekan peredaran jamu yang mengandung Bahan Kimia Obat di Indonesia, mendorong berbagai peneliti untuk mengembangkan teknik identifikasi bahan kimia dalam jamu. Saat ini Fakultas Farmasi Universitas Padjadjaran tengah mengembangkan berbagai strip indikator untuk mendeteksi adanya bahan kimia obat dalam jamu. Hanya dengan mencelupkan strip ke dalam sediaan jamu yang telah dilanutkan dalam pelarut, keberadaan bahan kimia dapat sesegera mungkin diketahui hanya dalam hitungan menit.

Keyword : obattradisional, bahan kimia obat, strip indikator

\section{Pendahuluan :}

Bangsa Indonesia telah lama mengenal dan menggunakan berbagai tanaman yang dipercaya berkhasiat dalam menanggulangi masalah kesehatan. Pengetahuan tentang khasiattanaman tersebut berdasarkan pada pengalaman dan ketrampilan secara turun temurun diwariskan dari generasi ke generasi.

Seiring dengan perkembangannya, tanaman-tanaman yang berkhasiat sebagai obat tersebut diolah, baik secara sederhana hingga menggunakan teknologi yang modern, sampai dihasilkan produk yang disebut dengan obat tradisional. Bangsa Indonesia telah lama mengenal dan menggunakan tanaman-tanaman obat sebagai salah satu upaya dalam menanggulangi masalah kesehatan.

Obat tradisional ialah bahan atau ramuan bahan yang berasal dari tumbuhan, hewan, mineral, sediaan sarian (galenik) atau campuran dari bahan tersebut, yang secara turun temurun telah digunakan untuk pengobatan berdasarkan pengalaman (Depkes RI,2000).

Obat tradisional Indonesia, saat ini dapat dikategorikan menjadi 3, yaitu sediaan jamu, sediaan obat herbal terstandar, dan sediaan fitofarmaka. Pengelompokan tersebut didasarkan pada perbedaan cara pembuatan serta jenis klaim penggunaan dan tingkat pembuktian khasiat (BPOM, 2004).

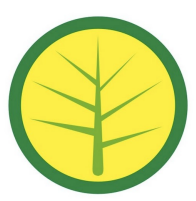

Logo Jamu

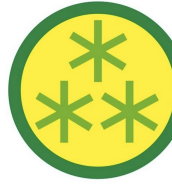

Logo Obat Herbal Terstandar

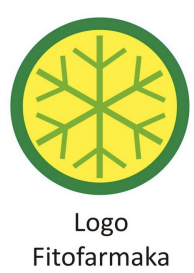

Fitofarmaka 
Penggunaan obat tradisional khususnya jamu di Indonesia cukup tinggi, hampir 50\% masyarakat Indonesia terbiasa mengkonsumsi jamu (Kemenkes RI, 2010). Tetapi peningkatan produksi, peredaran dan penggunaan jamu tersebut di sisi lain dicemani oleh adanya penambahan bahan kimia obat ke dalamnya.

Berdasarkan hasil pengawasan Badan Pengawas Obat dan Makanan (BPOM) di seluruh wilayah Indonesia dari bulan November 2013 sampai dengan Agustus 2014, ditemukan sebanyak 51 jamu yang mengandung BKO, dimana 42 diantaranya merupakan produk jamu yang tidak terdaftar (ilegal) dan sisanya merupakan produk jamu yang tidak sesuai dengan persetujuan pendaftaran (BPOM, 2014).

Bahan kimia obat (BKO) yang merupakan bahan kimia sintetik atau hasil isolasi, tidak boleh ditambahkan ke dalam obat tradisional karena bertentangan dengan Peraturan Menteri Kesehatan RI No. 246/Menkes/N/1990 tentang Izin Usaha Industri Obat Tradisional dan Pendaftaran Obat Tradisional. Jamu yang mengandung bahan kimia obat (BKO) dapat menyebabkan gangguan kesehatan serius, bahkan dapat berujung pada kematian karena bahan kimia obat (BKO) umumnya merupakan golongan obat keras yang harus diberikan sesuai dengan dosisterapinya.

Sulitnya menekan peredaran jamu yang mengandung BKO di Indonesia, mendorong berbagai peneliti untuk mengembangkan teknik identifikasi bahan kimia dalam jamu sehingga dapat memudahkan masyarakat dalam memilih dan mengkonsumsi jamu karena jamu alami dan jamu yang mengandung bahan kimia obatcukup sulitdibedakan secara kasatmata.

Saat ini Fakultas Farmasi Universitas Padjadjaran tengah mengembangkan berbagai strip indikator untuk mendeteksi adanya bahan kimia obatdalam jamu. Hanya dengan mencelupkan strip ke dalam sediaan jamu yang telah dilarutkan dalam pelarut, keberadaan bahan kimia dapat sesegera mungkin diketahui hanya dalam hitungan menit.

Strip indikator dibuat dari bahan polimer sebagai penyangga karena polimer memiliki pori-pori yang mampu ditembus masuk oleh pereaksi spesifik tetapi dapat menjaga pereaksi tidak tembus keluar dalamkurun waktu tertentu.

Inovasi yang saatini dilakukan masih membutuhkan banyak penyempumaan dan membutuhkan kolaborasi dari banyak pihak, agar jamu selalu menjadi tuan rumah di negeri sendiri tanpa harus terkotori oleh ulah produsen nakal.

Dengan adanya strip testini kedepan semua orang bisa berperan sebagai detektifbahan kimia obat dalam jamu dan bisa terhindar dari efek samping yang membahayakan.

\section{Daftar pustaka:}

Badan Pengawas Obatdan Makanan.2014. Public

Warning No.HM.04.01.1.43.11.14.7054 Tanggal 26 November 2014 tentang ObatTradisional Mengandung Bahan Kimia Obat. Tersedia di:

http://www.pom.go.id/new/admin/dat/20141126/261114 LampiranSiaranPe rsOTBKO.pdf

Kementrian Kesehatan Republik Indonesia.2010. RisetKesehatan Dasar (RISKESDAS) 2010.

Tersedia di:http://www.litbang.kemkes.go.id/sites/download/buku laporan/lapnas r

iskesdas2010/Laporan_riskesdas_2010.pdf

Badan Pengawas Obatdan Makanan.2005. Kriteria dan Tata Laksana Pendaftaran Obat Tradisional, Obat Herbal Terstandar dan Fitofarmaka. Jakarta: Badan Pengawas Obatdan Makanan Republik Indonesia.13. 